Article

\title{
Techno-Economic Evaluation of Hand Sanitiser Production Using Oil Palm Empty Fruit Bunch-Based Bioethanol by Simultaneous Saccharification and Fermentation (SSF) Process
}

\author{
Andre Fahriz Perdana Harahap ${ }^{1}$, Jabosar Ronggur Hamonangan Panjaitan ${ }^{2}$, \\ Catia Angli Curie ${ }^{1}$, Muhammad Yusuf Arya Ramadhan ${ }^{1}$, Penjit Srinophakun ${ }^{3}$ and \\ Misri Gozan ${ }^{1, *}$ \\ 1 Chemical Engineering Department, Faculty of Engineering, Universitas Indonesia, Depok 16424, Indonesia; \\ andrefahriz25@gmail.com (A.F.P.H.); catiacurie@gmail.com (C.A.C.); yra.ramadhan@gmail.com (M.Y.A.R.) \\ 2 Chemical Engineering Program, Institut Teknologi Sumatera, Lampung 35365, Indonesia; \\ jabosarronggur@gmail.com \\ 3 Chemical Engineering Department, Faculty of Engineering, Kasetsart University, Bangkok 10900, Thailand; \\ fengpjs@ku.ac.th \\ * Correspondence: mgozan@che.ui.ac.id; Tel.: +62-857-811-76292
}

Received: 22 July 2020; Accepted: 26 August 2020; Published: 29 August 2020

check for updates

Featured Application: The results of this work can be applied as the basis of consideration during the feasibility study step of plant design supposed to produce biomass-based bioethanol for commercial-scale hand sanitiser production. The results can contribute in the effort of converting agricultural waste into more valuable alternative product such as hand sanitiser which is urgently needed in global pandemic situation.

\begin{abstract}
Oil palm empty fruit bunch (OPEFB) is a potential raw material abundantly available for bioethanol production. However, the second-generation bioethanol is still not yet economically feasible. The COVID-19 pandemic increases the demand for ethanol as the primary ingredient of hand sanitisers. This study evaluates the techno-economic feasibility of hand sanitiser production using OPEFB-based bioethanol. OPEFB was alkaline-pretreated, and simultaneous saccharification and fermentation (SSF) was then performed by adding Saccharomyces cerevisiae and cellulose enzyme. The cellulose content of the OPEFB increased from $39.30 \%$ to $63.97 \%$ after pretreatment. The kinetic parameters of the OPEFB SSF at $35^{\circ} \mathrm{C}$, which included a $\mu$ max, $\mathrm{ks}$, and $\mathrm{kd}$ of $0.018 \mathrm{~h}^{-1}, 0.025 \mathrm{~g} / \mathrm{dm}^{3}$, and $0.213 \mathrm{~h}^{-1}$, respectively, were used as input in SuperPro Designer ${ }^{\circledR}$ v9.0. The total capital investment (TCI) and annual operating costs (AOC) of the plant were $\$ 645,000$ and $\$ 305,000$, respectively, at the capacity of $2000 \mathrm{~kg}$ OPEFB per batch. The batch time of the modelled plant was $219 \mathrm{~h}$, with a total annual production of 32,506.16 $\mathrm{kg}$ hand sanitiser. The minimum hand sanitiser selling price was found to be $\$ 10 / \mathrm{L}$, achieving a positive net present value (NPV) of $\$ 108,000$, showing that the plant is economically feasible.
\end{abstract}

Keywords: bioethanol; economic analysis; hand sanitiser; oil palm empty fruit bunch (OPEFB); simultaneous saccharification and fermentation; SuperPro Designer ${ }^{\circledR}$

\section{Introduction}

The World Health Organization (WHO) declared the outbreak of novel coronavirus SARS-CoV-2 as a global pandemic because of its ease of spread, severity it may cause and the lack of global 
precaution back then [1]. SARS-CoV-2 can be easily transmitted among humans through droplets, and human-coronaviruses can remain active on surfaces for up to nine days [2]. People may also be infected without showing severe symptoms. Practising cough and sneeze etiquette, as well as hand hygiene, is thus encouraged as a preventive measure. Following the WHO pandemic declaration, many countries then put in place strong restrictions and even lockdown to urge their citizens to limit physical contact and slow down the spread of Covid-19 as much as possible. However, as of June 2020, countries are beginning to relax the lockdown and restrictions because of economic demand. Since a vaccine for COVID-19 is yet to be developed, individual precautions must be practised in a more disciplined manner to prevent the spread of the virus. These have made hand sanitiser one of the most crucial items to have on hand.

Hand sanitiser helps the achievement of hand hygiene, especially in clinical settings or in conditions where water is unavailable. A study performed by Rai et al. has shown that single-use hand sanitiser packets are quicker to use than single-use moist towelettes. Thus, hand sanitisers are often preferred [3]. However, most hand sanitisers are not effective for non-enveloped viruses. Thus, despite being practical, hand sanitiser cannot fully replace hand washing, especially when the hand is visibly dirty or has come into contact with harmful chemicals [4-6].

Hand sanitisers can be classified into two groups: alcohol-based and alcohol-free sanitisers. Alcohol-based hand sanitisers are more common because of the ease of preparation, low cost and efficacy. The WHO has released a guide for the local production of alcohol-based hand-rub formulations. Generally, the alcohol used can be ethanol, isopropyl alcohol, or n-propanol. An alcohol content of $60-95 \% v / v$ is required for alcohol-based sanitisers to kill microbes effectively. Alcohols render microbes ineffective by damaging their lipid membranes and/or denaturing the proteins. The WHO-recommended formulations contain either $80 \% v / v$ of ethanol or $75 \% v / v$ of isopropyl alcohol with $1.450 \% v / v$ glycerol, $0.125 \% v / v$ hydrogen peroxide and water. Compared to isopropanol, ethanol is less irritant to the skin and more effective in killing a broader range of microbes [5-7].

Ethanol is commonly produced either from petroleum feedstock or from a sugar/starch feedstock, which is referred to as first-generation bioethanol. Neither is sustainable because petroleum is non-renewable while using sugar or starch as a feedstock interferes with food supplies and the utilisation of fertile land. Hence, the use of lignocellulosic feedstock, second-generation bioethanol, offers greater potential in terms of sustainability. This is because lignocellulosic materials are derived from various organic waste products and residues, including agricultural, forestry and household waste. Lignocellulose generally contains cellulose (40-60\%), hemicellulose (20-40\%) and lignin (10-25\%) with the exact content depends on the biomass source and harvest time. To produce ethanol, lignocellulosic feedstocks must undergo four basic steps: pretreatment, hydrolysis, fermentation and purification. The four steps may be assembled using the separate hydrolysis and fermentation (SHF) process, the simultaneous saccharification and fermentation (SSF) process, the simultaneous saccharification and co-fermentation (SSCF) process or consolidated bioprocessing (CBP). In SHF, each step stands alone. Thus, each can be performed under its optimum conditions. However, the capital cost of the SHF is high. In SSF, the sugar released from the saccharification process is directly fermented in the same reactor, limiting the risk of inhibition. SSF is currently the process used most often. Yet, saccharification and fermentation have different optimum conditions. Thus, it is still a challenge to perform both processes optimally in one reactor. SSCF differs from SSF in that it allows for the simultaneous fermentation of all the sugars produced from cellulose and hemicellulose. CBP, in turn, is different from the other processes because it uses only one type of microorganism to produce the enzymes for hydrolysis and to obtain fermentation. This process offers the most efficient process as it combines enzyme production, enzymatic hydrolysis and fermentation in one pot. Yet, the development of the CBP process is dependent upon the ability to engineer the appropriate microbes [8-10].

Many studies have been conducted to assess the production of bioethanol from various lignocellulose sources, such as from sugarcane bagasse using the SSF method and pretreated with 
white-rot fungi, from durian skin using the SSF method and cell encapsulation of S. cerevisiae, from paper waste using the SSF method, from corncobs using the SSCF method and scaled up to demo scale and from sugarcane bagasse using the CBP process [11-16]. Because of the complexity of the process, to date, lignocellulosic ethanol is still more expensive to produce compared to first-generation bioethanol. The productions of second-generation bioethanol are still covering less than $3 \%$ of total global bioethanol production where they are limited only at negligible amount in some demo plants around the world that work industrially but are not yet economically feasible $[17,18]$. One way of tackling this challenge is to produce various by-products in lignocellulosic ethanol plants. Rosales-Calderon and Arantes have reviewed several biochemicals with a minimum technology-readiness level of eight that can be produced alongside lignocellulosic ethanol [9]. The production of hand sanitisers can also be an option because of the ease of production and the increasing demand.

Oil palm empty fruit bunches (OPEFBs) are solid waste lignocellulosic biomass products of the oil palm industry, consisting of cellulose, hemicellulose and lignin. As much as 1.1 tonnes of OPEFBs can be produced from processing 1 tonne of palm oil. In 2011, the global production of OPEFBs amounted to 14.5 million tonnes, of which half were produced in Indonesia [19-21]. Their cellulose, hemicellulose and lignin contents give OPEFBs the potential to be converted into various biochemicals, such as bioethanol, furfural, formic acid and levulinic acid. Sahlan et al. have examined bioethanol production from OPEFBs using Rhizopus oryzae encapsulated using calcium alginate [14]. Panjaitan and Gozan have investigated formic acid production from the acid catalysed hydrolysis reaction of OPEFBs; Harahap et al. have further optimised the production process using the response surface methodology (RSM) method [22,23]. In addition, Gozan et al. have produced levulinic acid and furfural from OPEFBs and have evaluated its production kinetics [24].

As a demand and sustainability, palm oil serves many tasks such as excellent source of biomass, self-sufficient energy in processing, effective carbon sink, positive contribution to energy balance, sustainable practices and zero burning. The Indonesian Sustainable Palm Oil (ISPO) Certification Scheme is introduced by the Government of Indonesia as a mandatory requirement for all oil palm growers and mills to enhance the competitiveness of Palm Oil in the global market. For Malaysia, The Malaysian Sustainable Palm Oil (MSPO) Certification Scheme is the national scheme in Malaysia for oil palm plantations, independent and organised smallholdings, and palm oil processing facilities to be certified against the requirements of the MSPO Standards. The MSPO Certification Scheme provides the general principles for plantations and palm oil processing facilities to ensure that the palm oil products are produced in a responsible and sustainable manner [25].

Process simulation can be used to gain a better understanding of particular processes and their behaviours in real life. Simulation can be used to conduct experiments to evaluate behaviours or alternatives to chemical process systems [26]. To simulate a process, process engineering software needs specific scientific abilities, including, but not limited to, the ability to accurately describe the physical properties of pure components and complex mixtures, the ability to model a large variety of reactors and unit operations, and the computational and numerical techniques needed to solve a wide variety of different mathematical equations [27].

After thoroughly analysing a chemical process system, an economic analysis is an important step in developing better knowledge about that process. There are several parameters used to measure the investment performance of the production of chemical products, including, but not limited to, the internal rate of return (IRR), the net present value (NPV), and the payback period (PBP). The net present value is the difference between the present value of cash inflows and outflows used to analyse the profitability of the project. The internal rate of return is a value representing the profitability potential of the project as a form of discount rate that reduces the NPV of the project to zero. The payback period is the amount of time needed to recover the initial investment from the project. The rate of investment (ROI) is a percentage showing the efficiency of a project calculated from the net profit divided by the total cost of investment [28]. 
Advances in computational technology and improvements in modelling techniques have enabled easier access to quantitative predictions of complex systems' behaviours; in particular, mass and energy balances could, with further implementation, be used to accurately design unit operations. Process simulation has been commonly utilised in real-world chemical engineering industries to perform system analysis and synthesis [29]. Some of the leading commercial process simulation software packages today include Aspen Plus ${ }^{\circledR}$, Aspen HYSYS ${ }^{\circledR}$, CHEMCAD and PRO/II with PROVISION. The above simulators have been designed to model primarily continuous processes and their transient behaviour for process control purposes. Most bioprocess and biorefinery products, however, are produced in batch and semi-continuous modes. Such processes are best modelled with batch process simulators that account for time-dependencies and the sequencing of events. It is not difficult to switch between simulators once the principles of process simulation have been understood by the engineers [30]. SuperPro Designer ${ }^{\circledR}$ v.9.0. (Intelligen, Inc., Scotch Plains, NJ, USA, 2019) is one of the simulators specifically developed to simulate batch process systems. SuperPro Designer ${ }^{\circledR}$ also has the capability to perform comprehensive economic analyses, which is not limited to calculating total capital investment, NPV, IRR and PBP but can also perform detailed calculations of operational expenditure (OPEX) by enabling the customisation of staffing, utility pricing, and process scheduling. Therefore, SuperPro Designer ${ }^{\circledR}$ is perfect for the simulation needed in this study.

Until now, there have been no articles yet addressing the economic feasibility to produce value-added product like hand sanitiser, which is globally needed in the current pandemic situation, from under-utilised resource like OPEFBs. This study aims to provide an alternative application for second-generation bioethanol, combining both laboratory and modelling studies. A hand sanitiser plant utilising OPEFB as its feedstock was designed, and the kinetic parameters of the production of bioethanol from OPEFB using the SSF method were analysed. The obtained parameters were then used in the designed process simulation using SuperPro Designer ${ }^{\circledR}$ to evaluate the economic viability of this hand sanitiser plant.

\section{Materials and Methods}

\subsection{Kinetic Evaluation of Fermentation}

\subsubsection{Preparation of Materials}

The OPEFB used as the raw material for bioethanol production in this study was kindly received from the Indonesian government-owned palm oil plantation company PTPN (PT Perkebunan Nusantara) VIII Kertajaya, located in Banten, Indonesia. Before being used, the OPEFB was first reduced in size by cutting and grinding it in a laboratory-scale wood grinder (PT. Enerba Teknologi, Tangerang Selatan, Banten, Indonesia). The obtained OPEFB fibre was sifted through a 40-mesh stainless steel wire filter in order to obtain a uniform size of raw material, as shown in Figure 1. The OPEFB fibre was then washed under clean running water to remove the attached dirt and finally dried in an oven at $80^{\circ} \mathrm{C}$ for $24 \mathrm{~h}$. Cellulase enzymes from Trichoderma reesei ATCC 26921 and yeast Saccharomyces cerevisiae Type-1 were purchased from Sigma Aldrich (St. Louis, MO, USA). Both the cellulase and the yeast were stored in a refrigerator at $10{ }^{\circ} \mathrm{C}$ before being used. All other analytical-grade chemical reagents, like citrate buffer and sodium hydroxide, were purchased from Merck (Darmstadt, Hesse, Germany). 

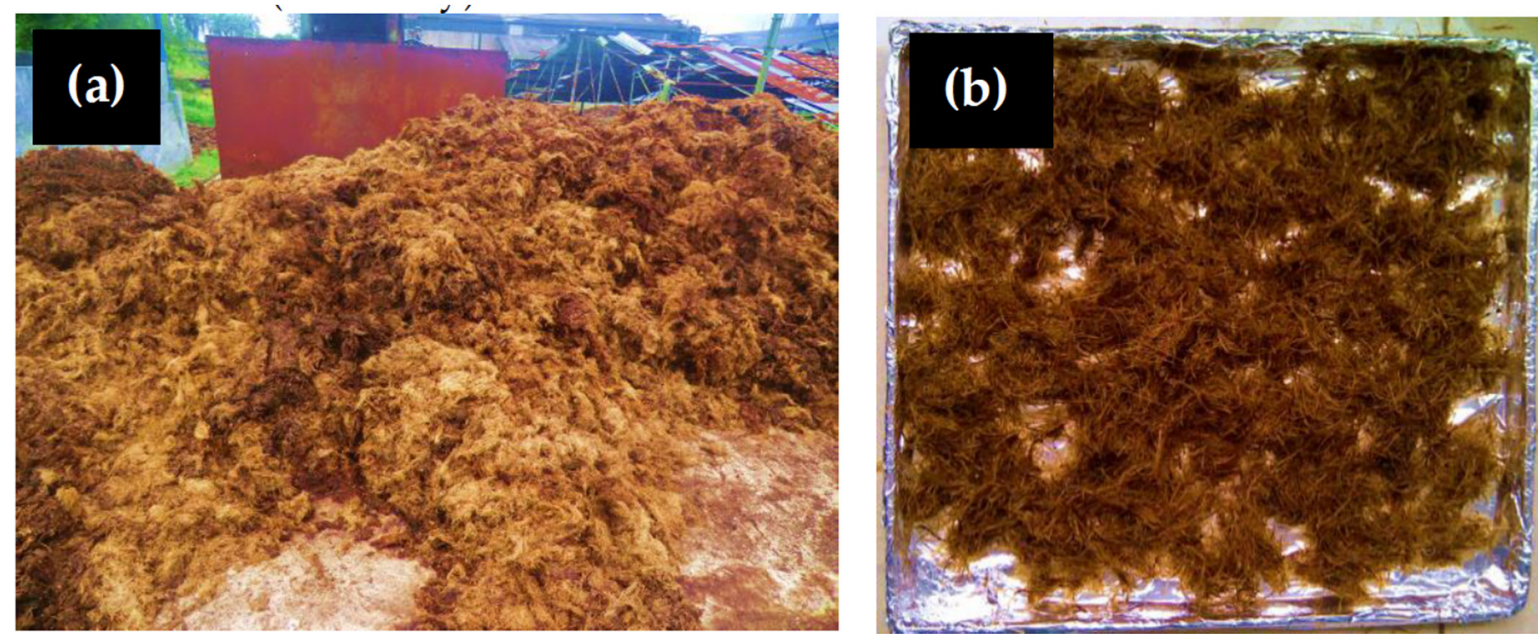

Figure 1. OPEFB before (a) and after (b) being ground as raw material for bioethanol production.

\subsubsection{OPEFB Pretreatment and Analysis}

OPEFB that will be used as a raw material for SSF must first be pretreated to remove its lignin content, thus enhancing the accessibility of the cellulase enzyme to the cellulose for further bioethanol conversion from glucose [31]. In this study, an alkaline pretreatment method using sodium hydroxide as the solvent was applied, according to Zulkiple et al. [32]. Pretreatment was performed by adding $30 \mathrm{~g}$ of the OPEFB sample into a 10\% sodium hydroxide solution with a 1:10 solid-to-liquid ratio. The mixture was then heated to $120^{\circ} \mathrm{C}$ for $2 \mathrm{~h}$ in an autoclave reactor (CV. Pugar Mandiri Teknik, Bandung, West Java, Indonesia) and cooled down at room temperature. The pretreated OPEFB was separated from the solvent, known as black liquor, using a stainless-steel wire filter. It was then washed with clean hot water to remove any remaining sodium hydroxide until neutrality was attained and dried in an oven at $95^{\circ} \mathrm{C}$ for $24 \mathrm{~h}$. The pretreated OPEFB was then analysed for its cellulose, hemicellulose, lignin and ash contents according to SNI 0444:2009, SNI 14-1304-1989, SNI 0492:2008 and SNI 0442:2009, respectively [33-36]. At this stage, the OPEFB was ready to be used for bioethanol production using the SSF method.

\subsubsection{Simultaneous Saccharification and Fermentation}

The SSF medium consisted of $15 \mathrm{~g}$ of pretreated OPEFB, $200 \mathrm{~mL}$ of $0.05 \mathrm{M}$ citrate buffer (pH 4.8), $1 \mathrm{~mL}$ of cellulase enzyme and $5 \mathrm{~g}$ of dry yeast. The mixture of OPEFB and citrate buffer was first sterilised at $121^{\circ} \mathrm{C}$ for $20 \mathrm{~min}$ in an autoclave. The mixture was then cooled down to room temperature and added to both the cellulase enzyme and the dry yeast. The SSF was performed in an Erlenmeyer flask (DWK Life Sciences GmbH, Mainz, Germany) closed tightly with aluminium foil. The flask was then incubated in an orbital shaker (Thermo Fisher Scientific, Waltham, MA, USA) at $150 \mathrm{rpm}$ for $96 \mathrm{~h}$. These experiments were conducted for temperature variations of $30^{\circ} \mathrm{C}, 32^{\circ} \mathrm{C}$ and $35^{\circ} \mathrm{C}$ to give sufficient data for the determination of the kinetic parameters. Samples were taken at $24,48,72$ and $96 \mathrm{~h}$ to analyse the concentrations of glucose, yeast cells and bioethanol in the fermentation broths.

\subsubsection{Analysis of Fermentation Products}

The fermented cell and glucose concentrations were analysed using optical density and dinitrosalicylic acid (DNS) methods. The optical density and DNS analyses were performed using UV-vis spectroscopy (UV-M90, BEL Engineering srl (C, Monza, MB, Italy). The DNS analysis used a $575 \mathrm{~nm}$ wavelength; the blank solution was a DNS buffer citrate solution. The optical density analysis used a $600 \mathrm{~nm}$ wavelength; the blank solution was a citrate buffer solution. The bioethanol analysis 
was conducted using a SUPELCOWAX-10 gas chromatography analyser (Supelco Inc., Bellefonte, PA, USA) at $50^{\circ} \mathrm{C}$.

\subsubsection{Reaction Constants Determination}

The kinetic model of bioethanol production used in this study was chosen in accordance with Fogler (2004), under the assumption that there is no mass-transfer effect and that the influence of bioethanol as an inhibitor can be ignored [37]. The kinetic equation can, therefore, be simplified to:

- The kinetic equation for yeast cell formation:

$$
\frac{\mathrm{d} C_{\mathrm{C}}}{\mathrm{d} t}=\left(\mu \max \frac{C_{\mathrm{c}} \cdot C_{\mathrm{s}}}{k s+C \mathrm{~s}}-k d \cdot C \mathrm{c}\right)
$$

- The kinetic equation for product formation (bioethanol):

$$
\frac{\mathrm{d} C_{\mathrm{C}}}{\mathrm{d} t}=Y_{\frac{\mathrm{P}}{\mathrm{C}}} \cdot \mu \max \frac{C_{\mathrm{C}} \cdot C_{\mathrm{s}}}{k s+C_{\mathrm{s}}}
$$

- The kinetic equation for the residual substrate:

$$
\frac{\mathrm{d} C_{\mathrm{s}}}{\mathrm{d} t}=Y_{\frac{\mathrm{S}}{\mathrm{c}}} \cdot\left(\mu \max \frac{C_{\mathrm{c}} \cdot C_{\mathrm{s}}}{k \mathrm{~s}+C_{\mathrm{s}}}\right)-m \cdot C_{\mathrm{c}}
$$

From the equations, it is necessary to determine the four reaction rate constants $(\mu$ max, $\mathrm{ks}, \mathrm{kd}$ and $\mathrm{m}$ ). Experimental data were obtained for the cell, glucose and bioethanol concentrations over time, and the reaction rate constants could then be predicted by minimising the sum of the square error values between the experimental data and the prediction data that was formulated:

$$
S S=\sum_{\mathrm{i}} \sum_{\mathrm{j}}\left([j]_{\mathrm{i} \exp }-[j]_{\mathrm{i} \text { predicted }}\right)^{2}
$$

The sum of the square error value can be determined using fminsearch optimisation (the Nedler-Mead method) and MATLAB software (MATLAB 9.6, MathWorks, Natick, MA, USA, 2019).

\subsection{Hand Sanitiser Plant Design}

SuperPro Designer ${ }^{\circledR}$ v.9.0 was used to conducting the process simulation and economic assessment of this hand sanitiser plant. Process design should always be completed first in order to specify a step-by-step process as well as to determine the equipment that will be involved in the simulation. At this stage, users also input specific parameters and operating conditions directly in the software for each involved piece of equipment. To model this hand sanitiser plant, a capacity of $2000 \mathrm{~kg}$ per batch of OPEFB was determined. The plant is also assumed to be constructed inside a palm oil mill area to reduce the transportation cost associated with the OPEFB.

The first section of this hand sanitiser plant is the pretreatment section. In this section, OPEFB obtained from the palm oil mill is first reduced in size by a grinding machine. This equipment grinds the raw material from the palm oil mill into 40-mesh sized OPEFB for $1 \mathrm{~h}$. The size-reduced OPEFB is then transferred into a vertical-on-legs tank, where the alkaline pretreatment takes place at $120^{\circ} \mathrm{C}$ for $60 \mathrm{~min}$. The OPEFB is mixed with a $10 \%$ sodium hydroxide solution with a 1:10 solid-to-liquid ratio by means of an adjustable mixer before entering this tank. The mixture is then cooled in a cooler for $60 \mathrm{~min}$ from $120^{\circ} \mathrm{C}$ to $25^{\circ} \mathrm{C}$ before being washed. During the washing process, the OPEFB is washed with $0.02 \mathrm{~m}^{3} / \mathrm{kg}$ of water for $30 \mathrm{~min}$. This washing process is assumed to remove $60 \%$ of the water and $100 \%$ of the sodium hydroxide as aqueous waste known as black liquor. Some hemicellulose, lignin, and ash are also removed in this process, according to the pretreatment compositional analysis results. 
The second section of the plant is devoted to medium preparation and SSF. The pretreated OPEFB from the previous washing process is mixed with a citrate buffer $(0.380 \%$ citric acid, $0.720 \%$ sodium citrate and water) at 1:13.13 liquid-to-solid ratio by means of an adjustable mixer. The mixture is then sterilised using a heat steriliser at $120^{\circ} \mathrm{C}$ for $2 \mathrm{~h}$ to avoid contamination from other organisms and cooled back down to $35^{\circ} \mathrm{C}$. Cellulase and yeast at $0.5 \%$ and $1 \%$ of the mass ratio of the entering feed, respectively, are gradually added to the mixture by means of two serial adjustable mixers. The mixture is then finally ready to be transferred into a batch vessel fermenter operating at $35^{\circ} \mathrm{C}$ and equipped with a jacket for chilled water flow. SSF takes place in this fermenter, with three reactions occurring simultaneously. Equation (5) is related to the saccharification reaction. Equations (6) and (7) are related to ethanol production and cell formation, respectively. The batch time for SSF in this fermenter was set in such a way as to obtain the highest amount of bioethanol.

$$
\begin{gathered}
1.00 \text { cellulose }+13.13 \text { water } \rightarrow 2.21 \text { glucose } \\
1.00 \text { glucose } \rightarrow 2.09 \text { carbon dioxide }+1.91 \text { ethyl alcohol } \\
0.56 \text { glucose } \rightarrow 0.45 \text { carbon dioxide }+1.11 \text { water }+0.33 \text { yeast }
\end{gathered}
$$

Reaction rate constants obtained from the optimisation results will be used as values to be input in

\begin{tabular}{|c|c|}
\hline Reaction & Kinetics Parameters Input \\
\hline Glucose $\rightarrow$ Yeast cell & $\begin{array}{l}\frac{\mathrm{d} C_{\mathrm{C}}}{\mathrm{d} t}=\left[\mu \max \left[1-\frac{\mathrm{Cp}}{\mathrm{Cp}^{*}}\right] \frac{\mathrm{Cs}}{k s+C s}-k d\right] C \mathrm{C} \\
\text { Input: } \\
\alpha=1 \\
\mu \max =\mu \max \\
(\mathrm{S} 1-\mathrm{Term})=1 \\
(\mathrm{~S} 2-\text { Term })=\frac{C \mathrm{~s}}{k s+C s} \\
\beta=-k d \\
(\mathrm{~B}-\mathrm{Term})=C \mathrm{C}\end{array}$ \\
\hline Glucose $\rightarrow$ Ethanol & $\begin{array}{l}\frac{\mathrm{d} C_{\mathrm{C}}}{\mathrm{d} t}=\left[Y_{\frac{\mathrm{P}}{\mathrm{C}}} \cdot \mu \max \left[1-\frac{\mathrm{Cp}}{\mathrm{Cp}^{*}}\right] \frac{\mathrm{Cs}}{k s+C \mathrm{~s}}\right] C \mathrm{C} \\
\text { Input: } \\
\alpha=Y_{\frac{\mathrm{P}}{\mathrm{C}}}(\text { ethanol mass/cell mass) } \\
\mu \max =\mu \max \\
(\mathrm{S} 1-\text { Term })=1 \\
(\mathrm{~S} 2-\mathrm{Term})=\frac{\mathrm{Cs}_{\mathrm{s}}}{k s+C \mathrm{~s}} \\
\beta=0 \\
(\mathrm{~B}-\text { Term })=C \mathrm{C}\end{array}$ \\
\hline Glucose $\rightarrow$ Glucose(residue) & $\begin{array}{l}\frac{\mathrm{d} C_{\mathrm{s}}}{\mathrm{d} t}=\left[Y_{\frac{\mathrm{S}}{\mathrm{C}}} \cdot\left(\mu \max \left[1-\frac{C \mathrm{p}}{\mathrm{Cp}^{*}}\right] \frac{\mathrm{Cs}}{k s+C \mathrm{~s}}\right)-m\right] C \mathrm{C} \\
\text { Input: } \\
\alpha=Y_{\frac{\mathrm{S}}{\mathrm{C}}} \\
\mu \max =\mu \max \\
(\mathrm{S} 1-\mathrm{Term})=1 \\
(\mathrm{~S} 2-\mathrm{Term})=\frac{\mathrm{Cs}}{k s+C \mathrm{~s}} \\
\beta=-m \\
(\mathrm{~B}-\mathrm{Term})=C_{\mathrm{C}}\end{array}$ \\
\hline
\end{tabular}
the SuperPro Designer ${ }^{\circledR} \mathrm{V} 9.0$ Software. The kinetics parameters data input can be seen in Table 1 below.

Table 1. Kinetics parameters data used as inputs in SuperPro Designer ${ }^{\circledR}$.

The final section of the plant handles purification and hand sanitiser formulation. The purification is started with filtration for $2 \mathrm{~h}$ in a plate and frame filter, which is set to remove almost all solid fractions from the fermentation broth. The liquid fraction is then transferred into the first distillation column, called a beer column, for $6 \mathrm{~h}$ to separate the ethanol from the fermentation medium. Most of the water and fermentation medium are removed as bottom products. At the same time, concentrated 
ethanol is transferred to the second distillation column, called a rectifying column, to increase the ethanol concentration up to $96 \%$. The product is then cooled to $25^{\circ} \mathrm{C}$ and transferred into a blending tank, where 3\% hydrogen peroxide, $98 \%$ glycerol and water are added to fulfil the hand sanitiser requirements provided by the WHO. The mixture is agitated for $1 \mathrm{~h}$ to obtain a homogenous hand sanitiser formulation and is then transferred out as a final product. The complete process flow diagram for the described hand-sanitiser production process as formulated by SuperPro Designer ${ }^{\circledR} \mathrm{V} 9.0$ can be seen in Figure 2 below.

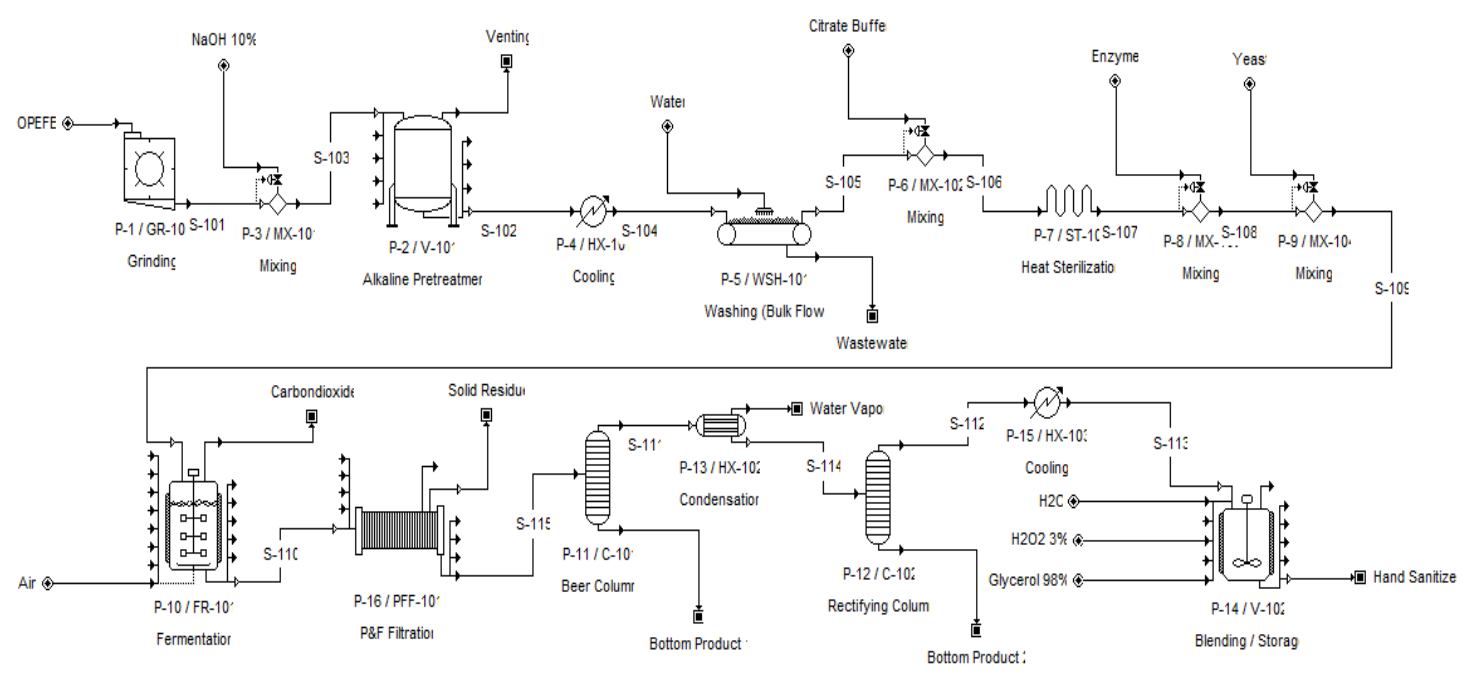

Figure 2. Complete process flow diagram of hand sanitiser production from OPEFB-based bioethanol in SuperPro Designer ${ }^{\circledR}$ v9.0.

The economic evaluation of this hand sanitiser plant was focused on the internal rate of return (IRR), the net present value (NPV), the payback period (PBP), the return on investment (ROI) and the gross margin of the operation. The calculations of those parameters were performed automatically by SuperPro Designer ${ }^{\circledR}$ v9.0. Before performing the economic evaluation, several terms should be assigned to this hand sanitiser plant, as can be seen in Table 2 below.

Table 2. Assigned terms for hand sanitiser plant's economic evaluation.

\begin{tabular}{cc}
\hline Parameters & Value \\
\hline Year of analysis & 2020 \\
Construction period & 30 months \\
Start-up period & 4 months \\
Project lifetime & 15 years \\
Interest rate & $7.0 \%$ \\
OPEFB capacity & $2000 \mathrm{~kg} / \mathrm{batch}$ \\
Labour wage & $\$ 0.92 / \mathrm{h}$ \\
\hline
\end{tabular}

\section{Results and Discussion}

\subsection{Kinetic Parameters of Fermentation}

The compositional analysis showed that the un-pretreated OPEFB used in this study contained $39.0 \%$ cellulose, $29.8 \%$ hemicellulose, $22.8 \%$ lignin and $1.7 \%$ ash, according to Gozan et al. [24]. After being alkaline-pretreated, there were significant changes to the composition of the OPEFB, as can be seen in Table 3. The pretreated OPEFB contained $63.97 \%$ cellulose, $10.58 \%$ hemicellulose, $19.39 \%$ lignin and $1.51 \%$ ash. This result proved that the delignification of the OPEFB occurred during the pretreatment process. In general, alkaline pretreatment of biomass at elevated temperatures will dissolve hemicellulose and lignin effectively, as the degradation of hemicellulose occurs much 
faster than that of cellulose [38]. This phenomenon can be seen from the decreasing amounts of both hemicellulose and lignin, but not of cellulose, in the pretreated OPEFB. The high cellulose content in the pretreated OPEFB would be very beneficial for the hydrolysis reaction to produce glucose during SSF.

Table 3. Composition of OPEFB after $\mathrm{NaOH}$ pretreatment.

\begin{tabular}{cc}
\hline Parameters & Composition (\%) \\
\hline Ash & 1.51 \\
Lignin & 19.39 \\
Cellulose & 63.97 \\
Hemicellulose & 10.58 \\
\hline
\end{tabular}

The effect of the fermentation time on the cell concentration at various fermentation temperatures can be seen in Figure 3b. Based on Figure 3b, cell concentration tends to increase with longer SSF times. This shows that the process of cell formation is still at an exponential stage because of the availability of sufficient substrate during the reaction and of reaction conditions that support the process of cell growth. Cell growth phenomena such as the lag phase, stationary phase and death phase have not been seen in the SSF process; this could be due to the large range of times for sampling processes. The lag phase in the cell formation can be predicted at $t \leq 24 \mathrm{~h}$. The exponential phase can be seen according to Figure $3 \mathrm{~b}$ from the 24 th $\mathrm{h}$ to the $72 \mathrm{nd} \mathrm{h}$, and after the $72 \mathrm{nd} \mathrm{h}$, cell growth looks constant or enters the stationary phase. On the other hand, the death phase was not seen in this study. This could be due to the abundant amount of substrate, which is indicated by the large residue of OPEFBs at the end of the SSF reaction $(t=96 \mathrm{~h})$. The death phase was also not seen in a study conducted by Amenaghawon et al. in which it was stated that the death phase is not seen in the cell growth phase because the substrate is still available for microorganisms to carry out metabolic processes [39].
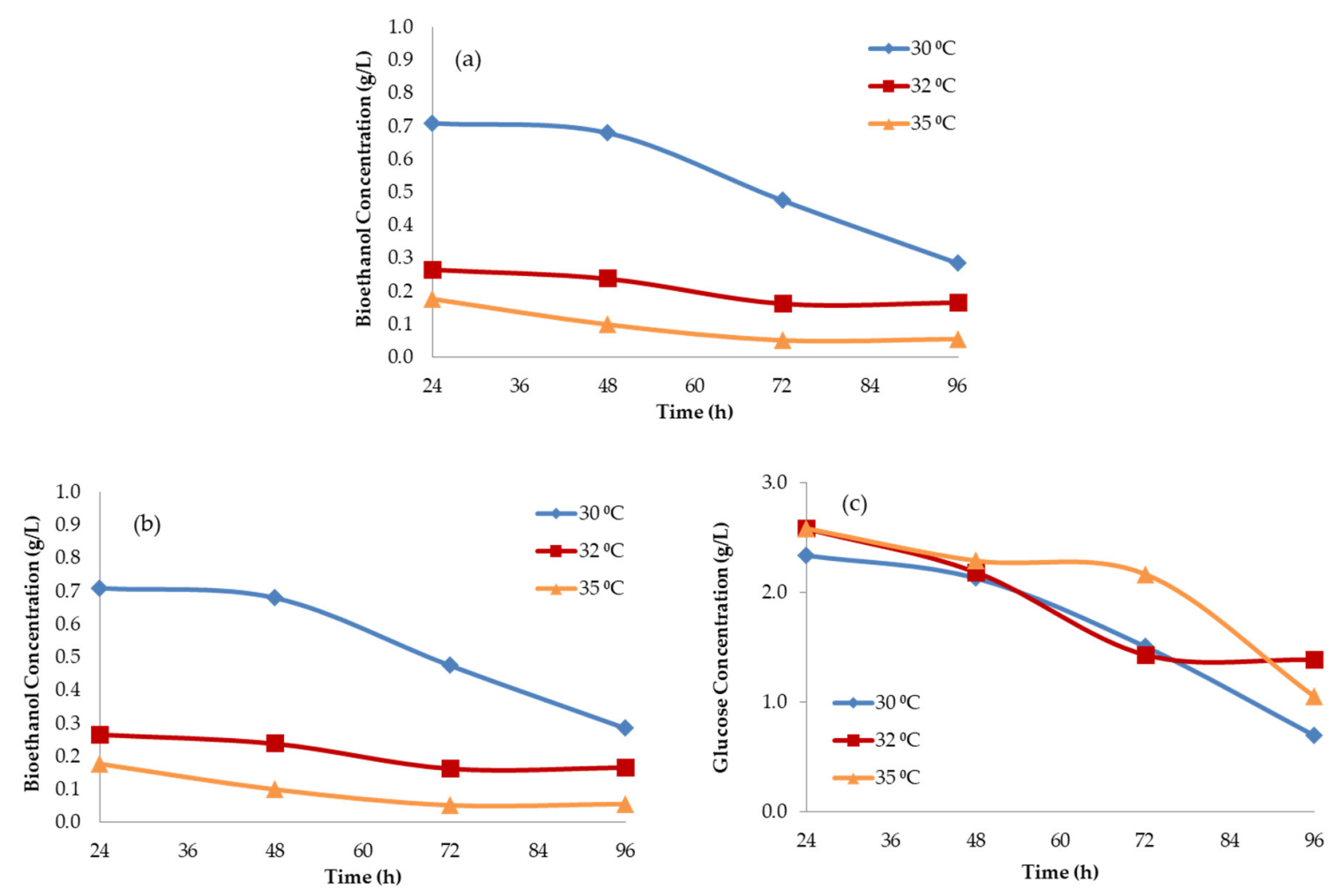

Figure 3. The concentration of bioethanol (a), yeast cell (b) and glucose (c) during SSF.

The effect of temperature on cell growth shows that the higher temperature of SSF produced higher microbial concentrations. This may have been due to the substrate that was used in this process. 
The substrate used in this research was OPEFB, which must be broken down into glucose using the cellulase enzyme. The enzymatic hydrolysis process was generally carried out at a temperature of $50{ }^{\circ} \mathrm{C}\left(\mathrm{T} \geq 30{ }^{\circ} \mathrm{C}\right)$. At $32{ }^{\circ} \mathrm{C}$ and $35^{\circ} \mathrm{C}$, the SSF process can cause the enzymatic hydrolysis of OPEFBs to be more effective and to produce more glucose than is produced at lower temperatures $\left(30^{\circ} \mathrm{C}\right)$. Glucose is used by yeast for cell growth.

The effect of the fermentation time on the glucose concentration at various fermentation temperatures can be seen in Figure 3c. Based on Figure 3c, glucose concentration tends to decrease with longer SSF times. This may occur because the glucose produced in enzymatic hydrolysis will be used directly by cells for growth processes and to produce bioethanol $[39,40]$.

The decrease in glucose concentration showed the same tendency at each SSF reaction temperature. This indicates that in the SSF process, glucose that has been formed as a result of enzymatic hydrolysis will be used directly by yeast as a carbon source to form bioethanol. $30^{\circ} \mathrm{C}$ was the temperature that showed the lowest glucose concentration at the end of the SSF reaction. This happened because, at this temperature, yeast cells make optimum use of glucose, which can be characterised by high ethanol concentrations.

The effect of the fermentation time on the bioethanol concentration at various fermentation temperatures can be seen in Figure 3a. Based on Figure 3a, the highest bioethanol concentration was $0.70 \mathrm{~g} / \mathrm{L}$. The longer reaction time of SSF produces lower bioethanol concentrations. The lower bioethanol concentration produced in this study was different from that produced in previous studies because, in general, the concentration of bioethanol will increase with longer fermentation times. The lower bioethanol concentration in this study could be due to the vaporisation of the ethanol.

The effect of temperature on bioethanol concentrations is quite significant. Figure 3a shows that a temperature of $30{ }^{\circ} \mathrm{C}$ with a 24 -h reaction time produced bioethanol at around $0.70 \mathrm{~g} / \mathrm{L}$. At $32{ }^{\circ} \mathrm{C}$ and $35{ }^{\circ} \mathrm{C}$ with 24 -h reaction time, the concentration of bioethanol dropped significantly to $0.26 \mathrm{~g} / \mathrm{L}$ and $0.17 \mathrm{~g} / \mathrm{L}$, respectively. This might have occurred because higher reaction temperatures can make fermentation processes ineffective. High temperatures can affect cell transport activity and the occurrence of ribosomal and enzyme denaturation and can cause fluidity problems in cell membranes [41]. Yeast optimally ferments glucose into bioethanol at $30^{\circ} \mathrm{C}$. Based on data obtained from the laboratory, the bioethanol concentration was very small. Therefore, the influence of bioethanol as an inhibitor in the SSF kinetics equation can be ignored.

Based on Figure 4 above, the kinetic model optimisation of cell, glucose and bioethanol concentrations shows some results that are not optimal. This could be due to the composition of the raw materials used in this study. The raw material used in this study was OPEFB, which consists of cellulose, hemicellulose and lignin. The hemicellulose and lignin contents in the raw material could have inhibited the enzymatic hydrolysis process and the fermentation process. However, overall, the kinetics model that was used in this study is suitable for experimental data and can describe the SSF process.

From the results of the kinetic model optimisation with cell, glucose and bioethanol concentrations, various kinetic constants on the bioethanol reaction can be obtained. The kinetics constants for the bioethanol fermentation reaction can be seen in Table 4 below.

Table 4. Determined kinetic parameters for bioethanol production.

\begin{tabular}{cccc}
\hline \multirow{2}{*}{ Kinetic Parameters } & \multicolumn{3}{c}{ Temperature $\left({ }^{\circ} \mathbf{C}\right)$} \\
\cline { 2 - 4 } & $\mathbf{3 0}$ & $\mathbf{3 2}$ & $\mathbf{3 5}$ \\
\hline$\mu \max \left(\mathrm{h}^{-1}\right)$ & 0.009 & 0.013 & 0.018 \\
$k s\left(\mathrm{~g} / \mathrm{dm}^{3}\right)$ & 0.004 & 0.010 & 0.025 \\
$k d\left(\mathrm{~h}^{-1}\right)$ & 0.009 & 0.009 & 0.213 \\
\hline
\end{tabular}



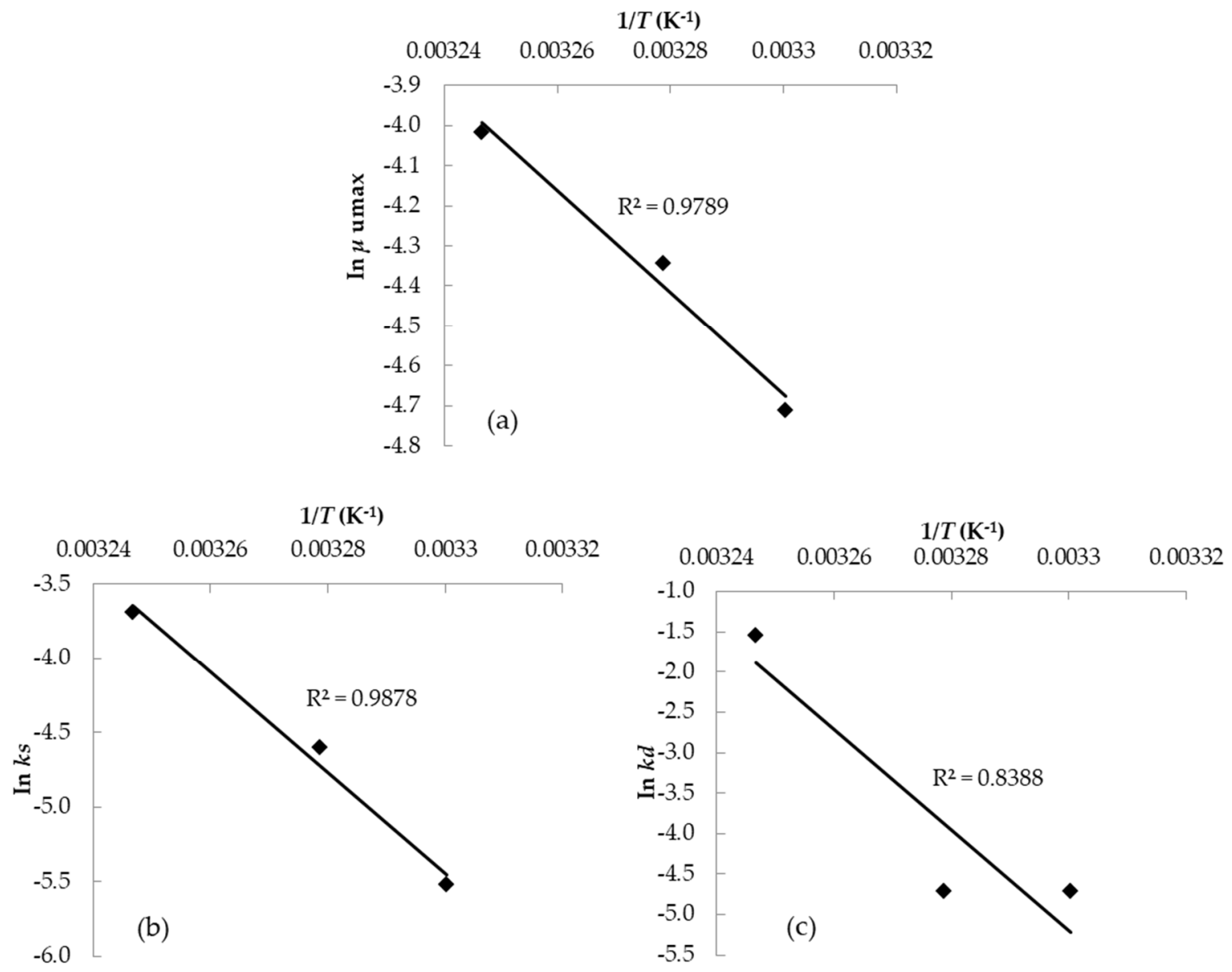

Figure 4. Arrhenius plot for SSF to determine $\mu \max (\mathbf{a}), k s(\mathbf{b})$ and $k d$ (c).

Based on Table 4, it can be seen that higher temperatures will increase the value of various reaction constants, such as $\mu$ max (maximum specific growth rate), $k s$ (Monod constant), $k d$ (cell death rate constant) and $\mathrm{m}$ (maintenance cell constant). One parameter that influences cell growth is $\mu$ max. The effect of ethanol on cell growth can be seen through the $\mu$ max parameter. When the ethanol concentration rises, $\mu$ max tends to decrease. The same phenomenon is also seen in the previous research conducted by Amenaghawon et al. [39]. This indicates that bioethanol is an inhibitor of the cell growth process.

\subsection{Process Simulation}

The simulation result obtained using SuperPro Designer ${ }^{\circledR} \mathrm{v} 9.0$ showed that fermentation time plays a significant role in determining the flowrate of products coming out of the fermenter when the kinetic parameters in Table 4 are applied. Figure 5 shows that the fermenter's output flowrate of bioethanol, glucose and yeast varied according to the fermentation time. The glucose flowrate decreased with increasing fermentation time as it was used as the substrate for bioethanol production. On the other hand, the bioethanol and yeast flowrates increased with increasing fermentation time, as they were both produced during fermentation. The glucose was completely consumed when the fermentation time was set to $192 \mathrm{~h}$. At this time, the flowrate of produced bioethanol was at a maximum. Thus, the fermentation time for this hand sanitiser plant was set to $192 \mathrm{~h}$ to obtain the maximum bioethanol yield with the minimum batch time. 


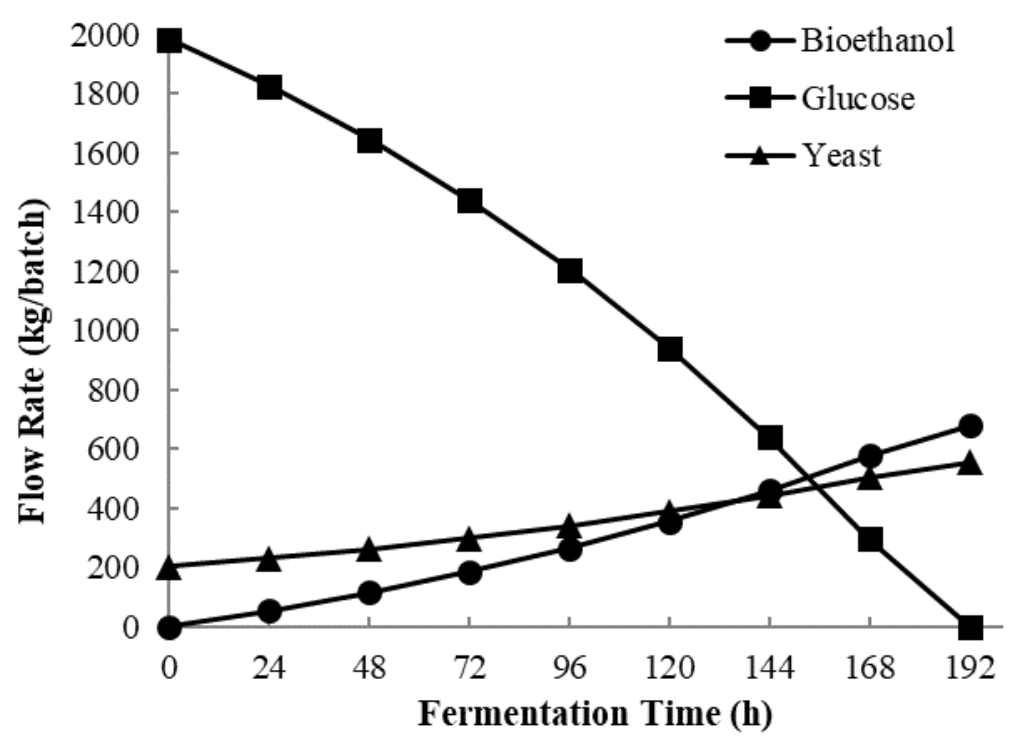

Figure 5. The relationship between fermentation time and flow rate of bioethanol, glucose and yeast leaving fermenter simulated by SuperPro Designer(C). v9.0.

When the fermentation time was set to $192 \mathrm{~h}$, the flowrate of produced bioethanol was $681 \mathrm{~kg}$ per batch, with a concentration of $3.4 \%$. The plate and frame filtration could separate solid and liquid fractions of fermentation broth, resulting in an increased bioethanol concentration of $3.5 \%$ in the liquid output stream. The first distillation process in the beer column increased the bioethanol concentration to $79.3 \%$ with the remaining water. The second distillation process in the rectifying column finally increased the bioethanol concentration to $96.2 \%$, as required by the WHO for use as a hand sanitiser raw material. At this point, the flowrate of bioethanol decreased to $651 \mathrm{~kg}$ due to some losses in the previous separation processes. Bioethanol was then mixed with the other raw materials, resulting in a final hand sanitiser product with a composition of $80.2 \%$ ethanol, $18.3 \%$ water, $1.4 \%$ glycerol and $0.1 \%$ hydrogen peroxide, as required by WHO standards. The overall results showed that this hand sanitiser plant design could produce $812.7 \mathrm{~kg}$ of hand sanitiser from $2000 \mathrm{~kg}$ of OPEFB for every batch.

The recipe scheduling information feature in SuperPro Designer ${ }^{\circledR} \mathrm{v} 9.0$ for this hand sanitiser plant showed that the batch time and minimum cycle time (excluding equipment shared across batches and auxiliary equipment) were 219 and $194 \mathrm{~h}$, respectively, with a total of 40 batches per year. This plant could, therefore, produce $32,506.16 \mathrm{~kg}$ of the total flow of hand sanitiser as the main product per year.

\subsection{Cost and Economic Parameters}

Investment performance measurement was conducted using several economic analyses, including the calculation of NPV, IRR, PBP and ROI. The calculations were performed using SuperPro Designer ${ }^{\circledR}$ v9.0 with several assumptions employed, based on the particulars of the Indonesian industry context, such as the number of holidays in a year, the labour price, the price of raw materials and the risk-free rate.

This section presents the estimation of the total capital investment cost (TCI), the annual operating cost (AOC) and the unit production cost of the hand-sanitiser product. The project is assumed to have a lifetime of 10 years and an annual operating time of 330 days (11 months). The depreciation of the capital investment was calculated using the straight-line method for a period of 10 years and a salvage value equal to $5 \%$ of the initial cost. The TCI of the plant was estimated according to the equipment purchase cost (EPC) following a well-established engineering methodology described in detail in the literature [42]. The equipment sizes were calculated using the simulation tool, based on the mass and energy balances. The EPC was estimated according to information from vendors, literature sources, and the SuperPro Designer ${ }^{\circledR}$ v9.0 equipment cost database. The total investment was estimated at $\$ 645,000$; the breakdown of the TCI is presented in Table 5 below. 
Table 5. Fixed capital estimate summary (2020 prices in \$).

\begin{tabular}{ll}
\hline \multicolumn{2}{l}{ Total Plant Direct Cost (TPDC) } \\
\hline 1. Equipment purchase cost & 101,000 \\
2. Installation & 33,000 \\
3. Process piping & 35,000 \\
4. Instrumentation & 41,000 \\
5. Insulation & 3000 \\
6. Electrical & 10,000 \\
7. Buildings & 46,000 \\
8. Yard improvement & 15,000 \\
9. Auxiliary facilities & 41,000 \\
TPDC & 325,000 \\
\hline Total Plant Indirect Cost (TPIC) & \\
\hline 10. Engineering & 81,000 \\
11. Construction & 114,000 \\
TPIC & 195,000 \\
\hline Total Plant Cost (TPC = TPDC + TPIC) & \\
\hline TPC & 520,000 \\
\hline Contractor's Fee and Contingency (CFC) & 59,000 \\
\hline 12. Contractor's Fee & 78,000 \\
13. Contingency & \\
CFC & \\
\hline Direct Fixed Capital Cost (DFC = TPC + CFC) & \\
\hline DFC & \\
\hline
\end{tabular}

The calculation of the annual operating cost (AOC) was conducted to determine the influence of operating components on the product cost. The calculated AOC for this plant was $\$ 305,000$; its breakdown is summarised in Figure 6. As shown in Figure 6, the largest percentage of the AOC is facility-dependent costs, which consist of capital depreciation, maintenance, insurance and overheads [43]. This can be explained, as the high value of the TCI and the relatively short lifetime of the plant lead to higher annual depreciation. The second highest cost contributor is utilities, which consist of standard electrical power, steam (low pressure and high pressure), and a large amount of cooling and chilled water, with a total annual utility cost of $\$ 95,749$. The highest contributor to the utility cost is electricity, at $\$ 58,807$ annually, or more than $61 \%$ of the utility cost. This is a result of the long period of fermentation that leads to high electricity consumption for processes such as agitation and temperature control. Raw materials, despite the low price of OPEFB, contribute to $22 \%$ of the AOC. The breakdown of raw material and utility costs can be seen in Table 6 .

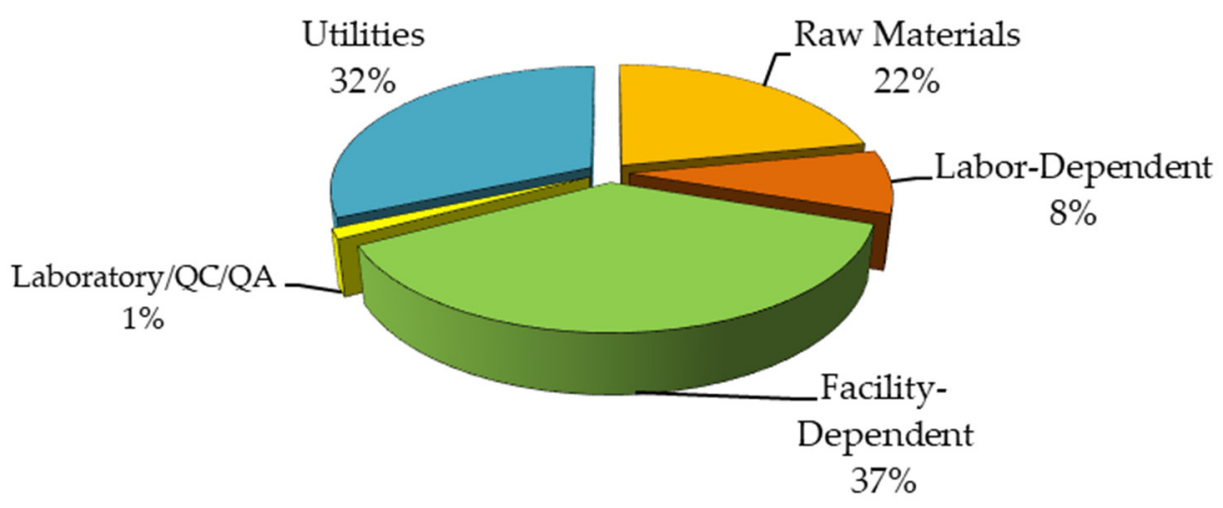

Figure 6. Annual operating cost breakdown. 
Table 6. A detailed list of materials and utilities cost.

\begin{tabular}{ccccc}
\hline Material/Utility & Unit Cost (\$) & Annual Amount & Reference Unit & Annual Cost (\$) \\
\hline Air & 0.00 & $5,914,956$ & $\mathrm{~kg}$ & 0 \\
Cellulase & 2.50 & 4058 & $\mathrm{~kg}$ & 10,146 \\
Citric Acid & 0.63 & 2866 & $\mathrm{~kg}$ & 1791 \\
Glycerol 98\% & 0.60 & 471 & $\mathrm{~kg}$ & 283 \\
$\mathrm{H}_{2} \mathrm{O}_{2} 3 \%$ & 0.40 & 1356 & $\mathrm{~kg}$ & 542 \\
OPEFB & 0.01 & 80,000 & $\mathrm{~kg}$ & 488 \\
Sodium Citrate & 0.76 & 5431 & $\mathrm{~kg}$ & 4127 \\
Sodium Hydroxide & 0.43 & 80,000 & $\mathrm{~kg}$ & 34,000 \\
Water & 0.01 & 4600 & $\mathrm{MT}$ & 46 \\
Yeast & 1.95 & 8158 & $\mathrm{~kW}-\mathrm{h}$ & 15,907 \\
Standard Power & 0.10 & 588,067 & $\mathrm{MT}$ & 58,807 \\
Low Pressure Steam & 3.34 & 1983 & $\mathrm{MT}$ & 6624 \\
High Pressure Steam & 5.78 & 1119 & $\mathrm{MT}$ & 6468 \\
Cooling Water & 0.05 & 186,277 & $\mathrm{MT}$ & 9314 \\
Chilled Water & 0.19 & 78,573 & & 14,536 \\
\hline
\end{tabular}

One of the reasons why this project could be economically beneficial is the low cost of labour in Indonesia. The actual minimum wage of labour in Indonesia varies depending on location. In this study, we used the highest value of minimum wage in Indonesia for labour and blue-collar jobs, which is about $\$ 0.9 /$ labour-h. The annual cost for operators as labour in this plant was found to be $\$ 24,996$ with a total annual amount of $27,170 \mathrm{~h}$, and it contributes to about $8 \%$ of the AOC.

After calculating the TCI and AOC, the unit production cost of the hand sanitiser product was then calculated at $\$ 9.37$ per $\mathrm{kg}$ of the main product. Since hand-sanitiser products are sold by volume, we determined the product selling price in USD/L. We varied the product selling price to further analyse the investment performance and to obtain the best-selling price. The calculation was performed using SuperPro Designer ${ }^{\circledR}$, and the parameters we focused on were IRR, PBP, gross margin, ROI and NPV. We wanted to obtain the selling price most feasible for penetrating the market in Indonesia, most likely to be economically beneficial and most able to fulfil the standard economic parameters of the market. The detailed data pertaining to the effect of product price variation can be seen in Table 7 below.

Table 7. Effect of hand sanitiser price on some economic parameters in this study.

\begin{tabular}{cccccr}
\hline $\begin{array}{c}\text { Product Price } \\
\text { (USD/L) }\end{array}$ & $\begin{array}{c}\text { IRR } \\
(\mathbf{\%})\end{array}$ & $\begin{array}{c}\text { PBP } \\
\text { (Year) }\end{array}$ & $\begin{array}{c}\text { Gross Margin } \\
\mathbf{( \% )}\end{array}$ & $\begin{array}{c}\text { ROI } \\
\mathbf{( \% )}\end{array}$ & $\begin{array}{c}\text { NPV } \\
\text { (USD) }\end{array}$ \\
\hline 2 & N/A & N/A & -295 & -26 & $-1,824,000$ \\
4 & N/A & N/A & -97 & -14 & $-1,278,000$ \\
6 & N/A & N/A & -32 & -3 & $-732,000$ \\
8 & 0.4 & 10.9 & 1 & 9 & $-224,000$ \\
10 & 9.8 & 6.1 & 21 & 16 & 108,000 \\
12 & 17.0 & 4.3 & 34 & 24 & 440,000 \\
14 & 23.2 & 3.3 & 44 & 31 & 772,000 \\
16 & 28.7 & 2.6 & 51 & 38 & $1,104,000$ \\
\hline
\end{tabular}

\subsection{N/A: Not Available}

Based on the data mentioned above, it can be concluded that a product selling price of $\$ 10 / \mathrm{L}$ is the minimum selling price able to fulfil all the given parameters. The hand sanitiser product with a $\$ 10 / \mathrm{L}$ price produces a 9.8\% IRR, will break even at 6.1 years, and has an NPV of $\$ 108,000$ at the end of the plant's lifetime. With a gross margin of $21 \%$, the product has a lower value according to the average gross margin obtained by speciality chemical industries, which have gross margin values at $31.16 \%$ [44]. Therefore, we need to choose the product selling price that can fulfil this parameter. The price point of $\$ 12 / \mathrm{L}$ produces a gross margin value of $34 \%$ with a higher IRR and NPV compared 
to the $\$ 10 / \mathrm{L}$ price-point, with values of $17 \%$ and $\$ 440,000$, respectively. It also has a relatively short payback period, at about 4.3 years. These economic parameters are from the market's point of view, with the average product selling price of hand sanitiser in Indonesia being $\$ 0.87$ per $50 \mathrm{~mL}$, or about $\$ 17.40 / \mathrm{L}$, the product is economically competitive compared to the existing products in Indonesia.

\section{Conclusions}

This study explored the techno-economic evaluation of a hand sanitiser production plant using OPEFB-based bioethanol and the simultaneous saccharification and fermentation method. The kinetic parameters of bioethanol production using Saccharomyces cerevisiae in a laboratory-scale experiment were applied in SuperPro Designer ${ }^{\circledR} \mathrm{v} 9.0$ to process simulation and economic assessment. The batch time of this hand sanitiser plant was $219 \mathrm{~h}$, with a total of 40 batches per year. The total capital investment was calculated at $\$ 645,000$ with a production capacity of $2000 \mathrm{~kg}$ per batch and a total of $32,506.16 \mathrm{~kg}$ of hand sanitiser as the main product per year. The total annual operating cost of this plant was found to be $\$ 305,000$. The economic assessment performed by SuperPro Designer ${ }^{\circledR} \mathrm{v} 9.0$ showed that the minimum selling price of the hand sanitiser was $\$ 10 / \mathrm{L}$, which would result in a $9.8 \%$ IRR, a $21 \%$ gross margin, a $16 \%$ ROI, a $\$ 108,000$ NPV and a PBP of 6.1 years. These results have shown that hand sanitiser production from OPEFB-based bioethanol is economically feasible and can be implemented at a tolerable price as an alternative application for second-generation bioethanol from lignocellulosic biomass in order to produce hygiene-related products.

Author Contributions: Conceptualization, M.G.; data curation, J.R.H.P.; formal analysis, A.F.P.H. and J.R.H.P.; investigation, J.R.H.P.; methodology, C.A.C.; project administration, M.Y.A.R.; resources, M.Y.A.R.; software, A.F.P.H.; supervision, P.S.; validation, P.S. and M.G.; visualization, A.F.P.H., C.A.C. and M.G.; writing-original draft, A.F.P.H.; writing-review and editing, P.S. and M.G. All authors have read and agreed to the published version of the manuscript.

Funding: We gratefully acknowledge the publication grant from Universitas Indonesia through Publikasi Terindeks International (PUTI) program Nr. NKB-1415/UN2.RST/HKP.05.00/2020, and partial support from MIT-Indonesia Research Alliance (MIRA) managed by Institut Teknologi Bandung (ITB) through WCU Program.

Conflicts of Interest: The authors declare no conflict of interest.

\section{References}

1. World Health Organization (WHO). (27 April 2020). WHO Timeline-COVID-19. Available online: https: //www.who.int/news-room/detail/27-04-2020-who-timeline---covid-19 (accessed on 27 May 2020).

2. Kampf, G.; Todt, D.; Pfaender, S.; Steinmann, E. Persistence of Coronaviruses on Inanimate Surfaces and Their Inactivation with Biocidal Agents. J. Hosp. Infect. 2020, 104, 246-251. [CrossRef] [PubMed]

3. Rai, H.; Knighton, S.; Zabarsky, T.F.; Donskey, C.J. Comparison of Ethanol Hand Sanitizer Versus Moist Towelette Packets for Mealtime Patient Hand Hygiene. Am. J. Infect. Control. 2017, 45, 1033-1034. [CrossRef] [PubMed]

4. Foddai, A.C.G.; Grant, I.R.; Dean, M. Efficacy of Instant Hand Sanitizers against Foodborne Pathogens Compared with Hand Washing with Soap and Water in Food Preparation Settings: A Systematic Review. J. Food Prot. 2016, 79, 1040-1054. [CrossRef] [PubMed]

5. Jing, J.L.J.; Yi, T.P.; Bose, R.J.C.; McCarthy, J.R.; Tharmalingam, N.; Madheswaran, T. Hand Sanitizers: A Review on Formulation Aspects, Adverse Effects, and Regulations. Int. J. Environ. Res. Public Health 2020, 17, 3326. [CrossRef] [PubMed]

6. Golin, A.P.; Choi, D.; Ghahary, A. Hand Santizers: A Review of Ingredients, Mechanisms of Action, Modes of Delivery, and Efficacy against Coronaviruses. Am. J. Infect. Control. 2020, in press. [CrossRef]

7. WHO. (April 2010). Guide to Local Production: WHO-Recommended Handrub Formulations. Available online: https://www.who.int/gpsc/5may/Guide_to_Local_Production.pdf?ua=1 (accessed on 26 May 2020).

8. Rastogi, M.; Shrivastava, S. Recent Advances in Second Generation Bioethanol Production: An Insight to Pretreatment, Saccharification and Fermentation Processes. Renew. Sustain. Energy Rev. 2017, 80, 330-340. [CrossRef] 
9. Rosales-Calderon, O.; Arantes, V. A Review on Commercial-Scale High-Value Products That Can be Produced alongside Cellulosic Ethanol. Biotechnol. Biofuels 2019, 12, 240. [CrossRef]

10. Su, T.; Zhao, D.; Khodadadi, M.; Len, C. Lignocellulosic Biomass for Bioethanol: Recent Advances, Technology Trends, and Barriers to Industrial Development. Curr. Opin. Green Sustain. Chem. 2020, 24, 56-60. [CrossRef]

11. Samsuri, M.; Gozan, M.; Mardias, R.; Baiquni, M.; Hermansyah, H.; Wijanarko, A.; Prasetya, B.; Nasikin, M. Pemanfaatan Sellulosa Bagas untuk Produksi Ethanol Melalui Sakarifikasi dan Fermentasi Serentak dengan Enzim Xylanase. Makara 2007, 11, 17-24. [CrossRef]

12. Arlofa, N.; Gozan, M.; Pradita, T.; Jufri, M. Optimization of Bioethanol Production from Durian Skin by Encapsulation of Saccharomyces cerevisiae. Asian J. Chem. 2019, 31, 1027-1033. [CrossRef]

13. Darmawan, M.A.; Hermawan, Y.A.; Samsuri, M.; Gozan, M. Conversion of Paper Waste to Bioethanol using Selected Enzyme Combination (Cellulase and Cellobiase) Through Simultaneous Saccharification and Fermentation. In Proceedings of the 11th Regional Conference on Chemical Engineering (RCChE 2018), Yogyakarta, Indonesia, 7-8 November 2019; Teguh, A., Imam, P., Rochmadi, N., Rofiqoh Eviana, P., Eds.; American Institute of Physics Inc.: College Park, MD, USA, 2019.

14. Sahlan, M.; Hermansyah, H.; Wijanarko, A.; Gozan, M.; Lischer, K.; Ahmudi, A.; Pujianto, P. Ethanol Production by Encapsulated Rhyzopus oryzae from Oil Palm Empty Fruit Bunch. Evergreen 2020, 7, 92-96. [CrossRef]

15. Koppram, R.; Nielsen, F.; Albers, E. Simultaneous Saccharification and Co-Fermentation for Bioethanol Production using Corncobs at Lab, PDU and Demo Scales. Biotechnol. Biofuels 2013, 6. [CrossRef] [PubMed]

16. Khuong, L.D.; Kondo, R.; De Leon, R.; Anh, T.K.; Shimizu, K.; Kamei, I. Bioethanol Production from Alkaline-Pretreated Sugarcane Bagasse by Consolidated Bioprocessing using Phlebia sp. MG-60. Int. Biodeterior. Biodegrad. 2014, 88, 62-68. [CrossRef]

17. Lennartsson, P.R.; Erlandsson, P.; Taherzadeh, M.J. Integration of the First and Second Generation Bioethanol Processes and the Importance of By-Products. Bioresour. Technol. 2014, 165, 3-8. [CrossRef] [PubMed]

18. Sharma, B.; Larroche, C.; Dussap, C.G. Comprehensive Assessment of 2G Bioethanol Production. Bioresour. Technol. 2020, 313, 1-9. [CrossRef] [PubMed]

19. Shinoj, S.; Visvanathan, R.; Panigrahi, S.; Kochubabu, M. Oil Palm Fiber (OPF) and Its Composites: A Review. Ind. Crops Prod. 2011, 33, 7-22. [CrossRef]

20. Purwandari, F.A.; Sanjaya, A.P.; Millati, R.; Cahyanto, M.N.; Horváth, I.S.; Niklasson, C.; Taherzadeh, M.J. Pretreatment of Oil Palm Empty Fruit Bunch (OPEFB) by N-methylmorpholine-N-oxide (NMMO) for Biogas Production: Structural Changes and Digestion Improvement. Bioresour. Technol. 2013, 128, 461-466. [CrossRef]

21. Medina, J.D.C.; Woiciechowski, A.; Filho, A.Z.; Nigam, P.S.; Ramos, L.P.; Soccol, C.R. Steam Explosion Pretreatment of Oil Palm Empty Fruit Bunches (EFB) using Autocatalytic Hydrolysis: A Biorefinery Approach. Bioresour. Technol. in press. [CrossRef]

22. Panjaitan, J.R.H.; Gozan, M. Formic Acid Production from Palm Oil Empty Fruit Bunches. Int. J. Appl. Eng. Res. 2017, 12, 4382-4390.

23. Harahap, A.F.P.; Rahman, A.A.; Sadrina, I.N.; Gozan, M. Production of Formic Acid from Oil Palm Empty Fruit Bunch via Dilute Acid Hydrolysis by Response Surface Methodology. In Proceedings of the Broad Exposure to Science and Technology 2019 (BEST2019), Bali, Indonesia, 7-8 August 2019; IOP Publishing Ltd.: Bristol, UK, 2019.

24. Gozan, M.; Panjaitan, J.R.H.; Tristantini, D.; Alamsyah, R.; Yoo, Y.J. Evaluation of Separate and Simultaneous Kinetic Parameters for Levulinic Acid and Furfural Production from Pretreated Palm Oil Empty Fruit Bunches. Int. J. Chem. Eng. 2018, 2018,1-12. [CrossRef]

25. McInnes, A. A Comparison of Leading Palm Oil Certification Standards; Forest Peoples Programme: Moreton-in-Marsh, UK, 2017; pp. 5-37.

26. Bernhard, T. Definition and Scope of Systems Engineering. In Systems Engineering: Principles and Practice of Computer-Based Systems Engineering; John Wiley \& Sons Ltd.: Chichester, West Sussex, UK, 1993; pp. 1-23.

27. Dimian, A.; Bildea, C.; Kiss, A. Integrated Design and Simulation of Chemical Processes, 2nd ed.; Elsevier Science: Amsterdam, The Netherland, 2014; pp. 35-71.

28. Feibel, B.J. Investment Performance Measurement, 1st ed.; John Wiley \& Sons, Inc.: Hoboken, NJ, USA, 2003; pp. 215-298. 
29. Khor, C.; Elkamel, A.; Anderson, W. Incorporating the Systems Approach in Future Undergraduate Chemical Engineering Education Curriculum: Illustration via Computer-Aided Process Simulation Laboratory Exercises. World Rev. Sci. Technol. Sustain. Dev. 2008, 5, 402-413. [CrossRef]

30. Seider, W.D.; Seader, J.D.; Lewin, D.R.; Widagdo, S. Product and Process Design Principles: Synthesis, Analysis, and Evaluation, 3rd ed.; John Wiley \& Sons, Inc.: New York, NY, USA, 2004; pp. 110-147.

31. Zhang, K.; Pei, Z.; Wang, D. Organic Solvent Pretreatment of Lignocellulosic Biomass for Biofuels and Biochemicals: A Review. Bioresour. Technol. 2016, 199, 21-33. [CrossRef] [PubMed]

32. Zulkiple, N.; Maskat, M.Y.; Hassan, O. Pretreatment of Oil Palm Empty Fruit Fiber (OPEFB) with Aqueous Ammonia for High Production of Sugar. Procedia Chem. 2016, 18, 155-161. [CrossRef]

33. Badan Standardisasi Nasional (BSN). Standar Nasional Indonesia (Indonesian National Standardization) SNI 0444: 2009 Pulp—Cara Uji Kadar Selulosa Alfa, Beta dan Gamma; BSN: Jakarta, Indonesia, 2009.

34. Badan Standardisasi Nasional (BSN). Standar Nasional Indonesia (Indonesian National Standardization) SNI 14-1304-1989 Cara Uji Kadar Pentosan Pulp Kayu; BSN: Jakarta, Indonesia, 1989.

35. Badan Standardisasi Nasional (BSN). Standar Nasional Indonesia (Indonesian National Standardization) SNI 0492:2008 Pulp dan Kayu—Cara Uji Kadar Lignin-Metode Klason; BSN: Jakarta, Indonesia, 2008.

36. Badan Standardisasi Nasional (BSN). Standar Nasional Indonesia (Indonesian National Standardization) SNI 0442: 2009 Kertas, Karton, dan Pulp-Cara Uji Kadar Abu pada $525^{\circ}$ C; BSN: Jakarta, Indonesia, 2009.

37. Fogler, H.S. Elements of Chemical Reaction Engineering, 4th ed.; Prentice Hall: Laflin, PA, USA, 2006; pp. 91-98.

38. Fengel, D.; Wegener, G. Wood: Chemistry, Ultrastructure, Reactions, 2nd ed.; Walter de Gruyter: Berlin, Germany, 1989; pp. 162-197.

39. Amenaghawon, N.A.; Okieimen, C.O.; Ogbeide, S.E. Kinetic Modelling of Ethanol Inhibition during Alcohol Fermentation of Corn Stover using Saccharomyces cerevisiae. Int. J. Eng. Res. Appl. 2012, 2, 798-803.

40. Dodic, J.M.; Vucurovic, D.G.; Dodic, S.N.; Grahovac, J.A.; Popov, S.D.; Nedeljkovic, N.M. Kinetic Modelling of Batch Ethanol Production from Sugar Beet Raw Juice. Appl. Energy 2012, 99, 192-197. [CrossRef]

41. Phisalaphong, M.; Srirattana, N.; Tanthapanichakoon, W. Mathematical Modeling to Investigate Temperature Effect on Kinetic Parameters of Ethanol Fermentation. Biochem. Eng. J. 2006, 28, 36-43. [CrossRef]

42. Peters, M.S.; Timmerhaus, K.D. Plant Design and Economics for Chemical Engineers, 4th ed.; McGraw-Hill: New York, NY, USA, 1991; pp. 120-252.

43. Konda, N.M.; Shi, J.; Singh, S.; Blanch, H.W.; Simmons, B.A.; Marcuschamer, D.K. Understanding Cost Drivers and Economic Potential of Two Variants of Ionic Liquid Pretreatment for Cellulosic Biofuel Production. Biotechnol. Biofuels 2014, 7,1-11. [CrossRef]

44. Damodaran, A. (January 2020). Margins by Sector (US). Available online: http://pages.stern.nyu.edu/ adamodar/New_Home_Page/datafile/margin.html (accessed on 10 July 2020). 